Article

\title{
Single-Cell Tests to Explore the Reliability of Sofc Installations Operating Offshore
}

\author{
Nelson Thambiraj ${ }^{1,2,+}$, Ivar Waernhus ${ }^{2,+}$, Crina Suciu ${ }^{2, *, \dagger}$, Arild Vik ${ }^{2, \dagger}$ and \\ Alex C. Hoffmann ${ }^{1,+}$ (D) \\ 1 Department of Physics and Technology, University of Bergen, 5007 Bergen, Norway; \\ nelson.thambiraj@student.uib.no (N.T.); alex.hoffmann@uib.no (A.C.H.) \\ 2 CMR Prototech AS, Fantoft, 5072 Bergen, Norway; ivar.warnhus@prototech.no (I.W.); \\ arild.vik@prototech.no (A.V.) \\ * Correspondence: crina.silvia.ilea@prototech.no Tel.: +47-942-57-802 \\ + These authors contributed equally to this work.
}

Received: 3 March 2020; Accepted: 25 March 2020; Published: 2 April 2020

check for updates

\begin{abstract}
This paper studies the robustness of off-shore solid oxide fuel cell (SOFC) installations and the nature and causes of possible cell degradation in marine environments. Two important, cathode-related, impediments to ensuring SOFC reliability in off-shore installations are: cathode degradation due to salt contamination and oxygen depletion in the air supply. Short-term and long-term tests show the effect of salt contamination in the cathode feed on cell performance, and reveal the underlying cause of the degradation seen. SEM/X-ray Diffraction /(XRD) analyses made it possible to identify salt taken up in the cathode microstructure after the short-term testing while the macroscopic cell structure remained intact after the short-term tests. The long-term degradation was found to be more severe, and SEM images showed delamination at the cathode/electrolyte interface with salt present, something that was not seen after long-term testing without salt. The effect of oxygen depletion on the performance was also determined at three different temperatures using I-V curves.
\end{abstract}

Keywords: SOFC; reliability; contamination; salt; oxygen starvation; concentration polarization

\section{Introduction}

Fuel cells represent an important innovation within the energy conversion industry, converting the chemical energy in fuels, e.g., hydrogen or, in the case of high-temperature fuel cells, hydrocarbon fuels, directly to electricity without, as in combustion, the detour around heat energy with the need to convert this heat energy to mechanical or electrical energy, a process which is subject to the Carnot efficiency limitation. Fuel cell installations are easily scalable, they are noise-free and they emit no particulates and virtually no NOx, the energy conversion taking place at much lower temperatures than for combustion.

Fuel cells have longer lifetime and offer significantly higher power densities than batteries and are also smaller and lighter. Like batteries, they are suitable also for applications which require only low power output, such as laptop computers and other portable electronic devices and mobile phones [1].

For investors to invest in large-scale power conversion installations based on fuel cells, however, fuel cell installations need to be shown to be robust and reliable in the field. Herein lies an important challenge in fuel cell research and development today $[2,3]$.

Since the issue of robustness is so important for implementation of fuel cell technology in the main-stream energy conversion industry, this has received some attention in the research literature recently. Much of the literature focuses on the effects of contaminants in the fuel on the anode or the 
effect of oxygen starvation on the cells as a whole. Below we review some of the literature dedicated to the effect of impurities on fuel cell performance, concentrating on solid oxide fuel cells.

Cayan et al. [4] investigated the effects of the presence of coal-derived impurities in the anode feed to solid oxide fuel cells. They found that $\mathrm{Hg}, \mathrm{Si}, \mathrm{Zn}$ and $\mathrm{NH}_{3}$ do not lead to significant degradation. $\mathrm{Cl}$, $\mathrm{Sb}$, As, and $\mathrm{P}$, on the other hand, led to significant degradation of the fuel cell performance, attacking the Ni-YSZ anode.

Bao et al. [5] similarly investigated the effects of eight kinds of coal-derived contaminants on the working of Ni-YSZ/YSZ/LSM solid oxide fuel cells (SOFC) and found that As and P in the feed resulted in significant loss of performance at the lower operating temperatures due to the Ni phase in the anode being compromised. Microstructural analyses helped the authors to characterize the mechanisms behind the degradation. $\mathrm{Zn}, \mathrm{Hg}$ and $\mathrm{Sb}$ led to little degradation.

Cheng et al. [6] studied the effect of sulphur on the working of YSZ anodes in solid oxide fuel cells. Also Haga et al. [7] studied the effect of impurities, among other things sulphur compounds, on the working of solid oxide fuel cell cermet anodes. They found a direct initial drop in voltage when introducing the impurities, and also found a gradual additional drop in performance when the impurity was $\mathrm{CH}_{3} \mathrm{SH}$. They also found that $\mathrm{Cl}_{2}$ in the feed gave rise to nickel nanoparticles via the formation of gaseous $\mathrm{NiCl}_{2}$.

Horita et al. [8] studied the effects of impurities on the stability of solid oxide fuel cells. They studied the durability of a fuel cell stack for more than $5000 \mathrm{~h}$. They found a gradual loss of performance (linear in time) of about $1.5 \%$ per $1000 \mathrm{~h}$ during the operation. They found by secondary ion mass spectrometry that the contaminants were present in the cathode, their concentration increasing with increasing operation time.

Yan et al. [9] modelled numerically degradation of the performance of solid oxide fuel cells due to carbon deposition. They found that the bilayer interconnect that they were testing was more robust under carbon deposition than a conventional interconnect, and that the performance of the cell only degraded slightly due to carbon deposition.

Many studies understandably concentrate on the effect of impurities in the fuel supply on the anode side. There are, however, some studies that focus on the effect of impurities on the cathode side.

Xiong et al. [10] studied the degradation due to the presence of trace SOx in the air on the cathode of solid oxide fuel cells. They found rapid degradation of the performance of an SSC cathode both in the form of ohmic and concentration polarization due to the introduction of $\mathrm{SO}_{2}$ in the feed, while the performance of an LSM cathode decreased only slightly. They found that the formation of secondary phases, e.g., as strontium sulphate, was seen in the SSC cathode upon introduction of $\mathrm{SO}_{2}$, while this was not detected in the LSM cathode.

Two studies of the effect of salt in the feed to an fuel cell cathode, one in solid oxide fuel cells, were found in the literature. Mikkola et al. [11] studied the effect of salt in the air stream to a cathode of a PEM fuel cell. They injected $\mathrm{NaCl}$ in the air supply to the cell. They found that the degradation due to salt in the air feed was less than they had anticipated, and studied the microstructure of the cathode after the testing to pinpoint the reason for the degradation that they did see.

Liu et al. [3] studied the effect of salt, at two different concentrations, 30 and $600 \mathrm{ppm}$, in the air feed to solid oxide fuel cells operated at a fixed current density of $200 \mathrm{~mA} / \mathrm{cm}^{2}$. With salt at a concentration of $30 \mathrm{ppm}$ they found only moderate reduction in the cell voltage. When the salt concentration was increased to $600 \mathrm{ppm}$ and the cell operated for $24 \mathrm{~h}$, the cell voltage closely resembled that obtained with $30 \mathrm{ppm}$, i.e., only moderate reduction of the performance. In the conclusions of the paper the authors suggest that partial substitution of the $\mathrm{Sr}$ with $\mathrm{Na}$ could be responsible for the moderate reduction in the cell performance that they saw. They emphasize the need for longer-term testing.

We conclude from this study of the literature that most of the literature naturally enough focuses on the effects of impurities introduced with the fuel on the anode side of cells. For the operation of maritime fuel cell installations impurities on the cathode side may well pose a problem for the 
long-term performance of the installation. To our knowledge there are no studies in addition to that of Liu et al. [3] in the literature focusing on the likely disturbances leading to degradation in fuel cell installations offshore, and therefore no studies wherein complete I-V curves are presented or studies that involve long-term testing.

In this paper the focus is on SOFC installations working in a marine environment, namely:

1. To which extent individual cells will be degraded by the presence of salt $(\mathrm{NaCl})$ in the feed to an SOFC cathode, and the underlying reasons for any such degradation.

2. The effect of oxygen depletion in the air supply to a cell.

$\mathrm{I}-\mathrm{V}$ curves were generated to determine the cell performance both in short-term and long-term degradation tests with different salt concentrations in the cathode feed at three different temperatures, and the cell microstructure before and after the tests were investigated using scanning electron microscopy (SEM) in order to determine the underlying reasons for any changes in the performance.

$\mathrm{I}-\mathrm{V}$ curves were also generated under conditions of varying degrees of oxygen depletion in the feed to the cathode at three different realistic operating temperatures.

\section{Experimental}

\subsection{Test Set-Up}

The experiments use the set-up shown in Figure 1, details of the cell are also shown in Figure 1. The components used in the set-up are described below.

\subsubsection{Oven}

One of the main components of the experimental set-up is the oven. It is used to heat the cell to the required temperature. The oven is programmed with ramping (rate at which cell is heated: $1.6^{\circ} \mathrm{C} / \mathrm{min}$ ), set temperature (required temperature) and dwell time (time period during which the temperature is maintained).

\subsubsection{The Cell Itself}

The overall performance of SOFCs are determined by activation, ohmic and concentration polarisations. The electrolyte is the main contributor to the ohmic losses. The desired characteristics of an electrolyte to minimize ohmic losses are high ionic conductivity and small thickness. In this work, the electrolyte material used is yttria stabilised zirconia, or YSZ, which is widely used due to its excellent stability in both reducing and oxidising environments, even though its ionic resistivity, especially for the doping level used here, is not the lowest of the alternative electrolyte materials.

The single cell used for the experimental work is purchased from KERAFOL Keramische Folien $\mathrm{GmbH}$, Germany, the commercial name of this cell type being "KeraCell I". It is an Electrolyte-Supported Cell with NiO/YSZ type anode and ScSZ/LSM type cathode. The electrolyte is made of $3 \%$ Yttrium stabilised Zirconia (YSZ) and has a thickness of $85 \mu \mathrm{m}$. The diameters of the electrolyte and electrodes are $40 \mathrm{~mm}$ and $30 \mathrm{~mm}$ respectively (shown in Figure 2).

The key features of the cell are as follows:

- High power density

- Robust in nature for long term usage and in redox environments 


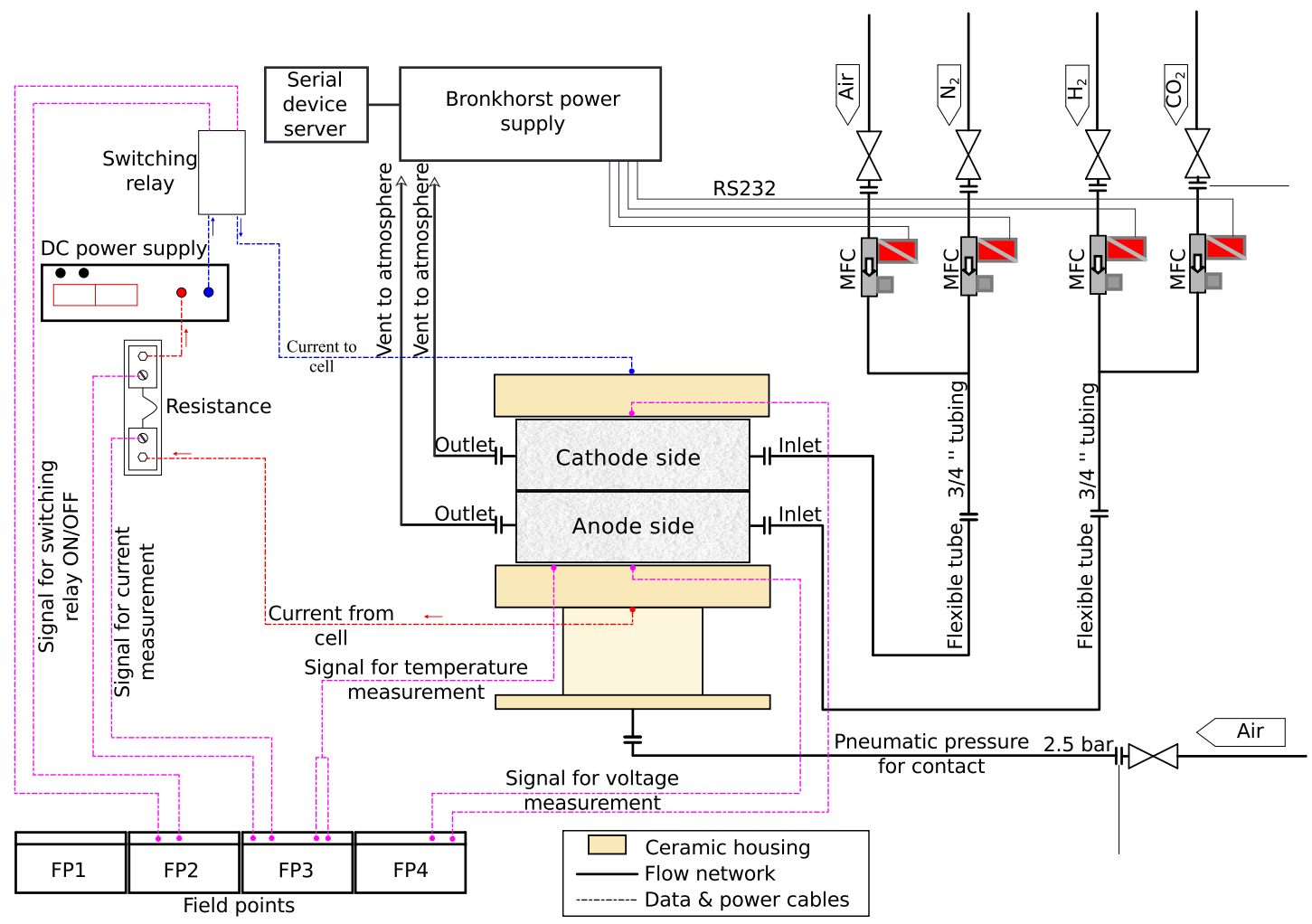

A

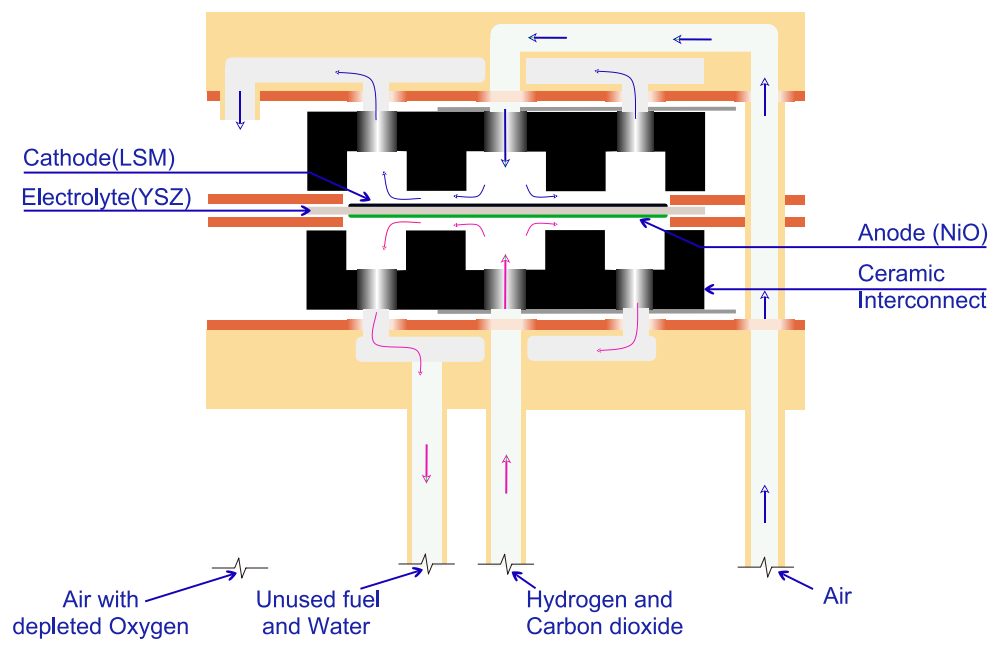

B

Figure 1. Piping and instrumentation diagram for the experimental set-up. (A) shows the whole setup, (B) a detail of the configuration around the cell itself 


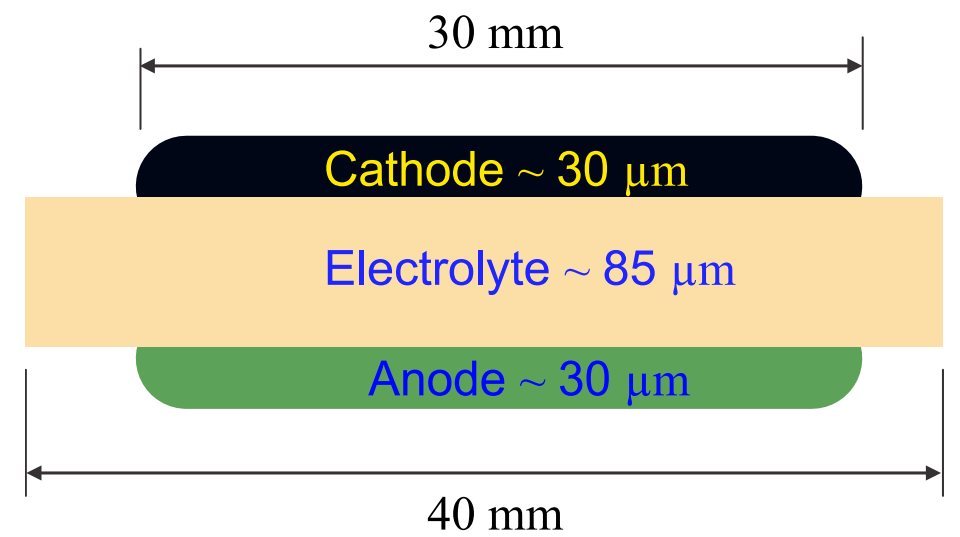

Figure 2. The circular, electrolyte-supported cell used in the experiments, the thicknesses of the electrodes and the electrolyte are indicated.

\subsubsection{Gas Handling System}

$\mathrm{H}_{2}$ and $\mathrm{CO}_{2}$ gases are supplied to the anode, while air and nitrogen are supplied to the cathode. Bronkhorst mass flow meters/controllers are installed on each of the gas lines and a common tube is connected to the fuel supply point of the set-up. A pneumatic compression force of $123 \times 10^{6} \mathrm{~N}$ was applied on the cell via the interconnects in order to achieve a better electrical contact. The air was supplied by $3 / 4$ inch tubing from the main valve to a pressure-regulating valve. From this valve a flexible hose was connected to the pneumatic piston cylinder arrangement on the test set-up.

\subsubsection{Field Points}

The voltage and the current across the cell and the temperature of the cell were measured using field-points. Field-points gave capabilities that improved the reliability of the test system. It provided online diagnostics and innovative architecture that modularized I/O functions and communications. Easy connectivity was also provided by screw terminals.

An external DC device was used for current control. This device was controlled by LabVIEW programs and made it possible to move along the I-V curve in a controlled manner. The voltage across the cell was measured using an NI 16-channel analogue voltage input module. The OCV was measured without allowing any current to pass through the cell and this was done by using the external device. This relay was controlled by a 8-channel fused sourcing digital output module. The current from the anode was measured using a known resistor and an NI 8-channel module.

The temperature was measured using a thermocouple which was connected to a field point serial device. Shared variables were created in LabVIEW for reading the voltage, current and cell temperature and to control the current supply using the relay. The Bronkhorst gas flow controller communicates digitally with the gas flow meter/controller through an RS232 and the gas flow controller device is controlled remotely from LabVIEW.

\subsubsection{Data Acquisition}

The experimental set-up used makes a variety of measurements that require signal conditioning before the raw signal is digitized by the data acquisition system. Each individual cell may generate up to $1 \mathrm{~V}$ and hence calibration is important to ensure accurate measurements. Monitoring output current requires signal conditioning and scaling to convert the data back to a current reading. Temperature is another variable that is monitored by thermocouples. Hydrogen, oxygen, nitrogen and airflow rates are measured by mass flow meters (see Figure 3). These meters generate pulses at a rate proportional to the gas flow rate. A counter monitors the pulse rate and this is converted into flow rate. 


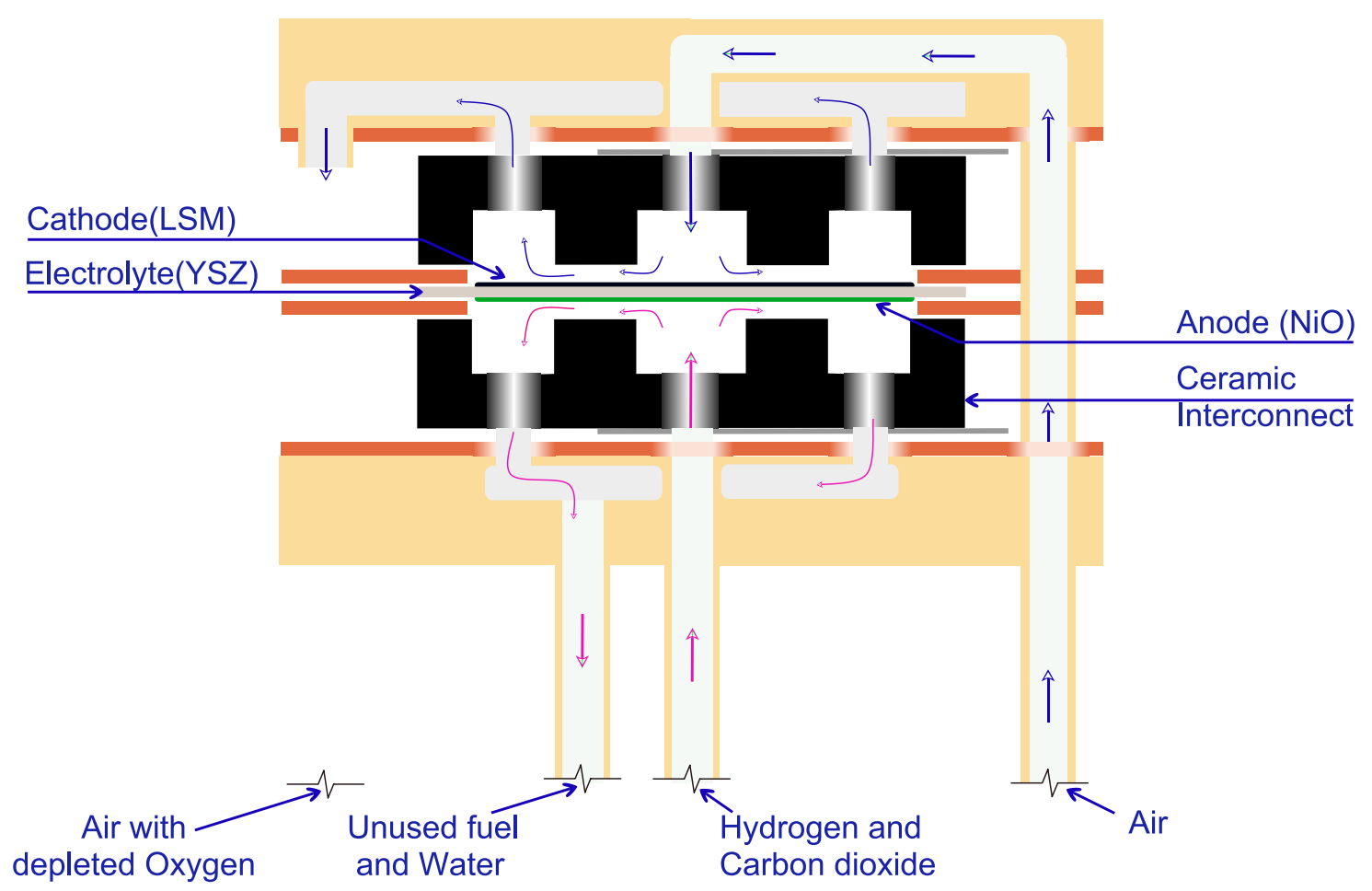

Figure 3. Simplified arrangement of the single cell experimental set-up used in the experiments, the flow directions are indicated.

The other tools used to prepare and characterize the cell are explained in the subsequent sections.

\subsubsection{Current-Collection Layers}

Additional layers can be applied to planar cells using screen printing (SP). The cells used for the experiments are provided with primary anode and cathode layers by the supplier, while additional current-collecting layers were formed on both electrodes in-house by SP [12]. Using efficient anode/cathode materials and structures will optimize the SOFC performance. The preparation process and the microstructure of the cathode strongly affect the concentration polarization resistance of the cathode [13].

\subsubsection{Characterization of the Layers}

In order to determine the local composition and morphology of the materials, two microscopic analysis methods, namely SEM and TEM (transmission electron microscopy) were used. SEM was used to analyse the surface of a sample, while TEM was used to analyse the internal structure by permeating a thin sliver or powder [14].

\subsection{Method}

\subsubsection{Short-Term Salt Degradation Tests}

In these tests the effect of salt on the cathode was evaluated for a relatively short period with the cell operating at a temperature of $850{ }^{\circ} \mathrm{C}$. The tests were conducted in three stages. For the first $70 \mathrm{~h}$, the cell was operated without any salt contamination. The salt was then introduced in the feed line and heated to a temperature of $600{ }^{\circ} \mathrm{C}$ (giving a molar concentration of $1.6 \mathrm{ppm}$ in the gaseous feed to the cathode, see [15]) and the cell operated for $14 \mathrm{~h}$. During the next stage the temperature of the solid salt in the feed line was increased to $770{ }^{\circ} \mathrm{C}$ (giving $250 \mathrm{ppm}$ ) for $50 \mathrm{~h}$ plus $18 \mathrm{~h}$ after the solid salt was replenished. 
The flow parameters during these tests were: Cathode feed: Air: $600 \mathrm{~mL} / \mathrm{min}, \mathrm{N}_{2}: 0 \mathrm{~mL} / \mathrm{min}$. Anode feed: $\mathrm{H}_{2}: 250 \mathrm{~mL} / \mathrm{min}, \mathrm{CO}_{2}: 75 \mathrm{~mL} / \mathrm{min}$.

\subsubsection{Long-Term Salt Degradation Tests}

In these tests the performance of cathodes subjected to salt contamination for a long period was studied. Three single cells were studied, two of which were operated for $850 \mathrm{~h}$, one of these two cells was contaminated with salt. The SEM images from these cells were compared to that of the third cell operated for a short duration without contamination or any load as a reference.

We should mention that the preparation of the cells for these tests was slightly different from those used for the short-term tests described above. Screen printing of NiO/LSM on the respective electrodes with embedded platinum mesh was avoided and this resulted in a reduction of losses thanks to thinner electrodes. In order to increase the current collecting layers on the cell, layers were screen printed onto the interconnects instead of on the electrodes themselves; two layers of LSM30 were screen printed on the cathode side, and one layer of $\mathrm{NiO}$ on the anode side using a precursor nanopowder prepared by a sol-gel process developed in-house [16]. The voltage across the cell was measured by means of a platinum wire making point contact directly on both the electrodes.

The flow parameters during these tests were: Cathode feed: Air: $2000 \mathrm{~mL} / \mathrm{min}, \mathrm{N}_{2}: 0 \mathrm{~mL} / \mathrm{min}$. Anode feed: $\mathrm{H}_{2}: 250 \mathrm{~mL} / \mathrm{min}, \mathrm{CO}_{2}: 75 \mathrm{~mL} / \mathrm{min}$.

The procedure was as follows. After the cell was heated up to the operating temperature in an electric furnace, the anode was reduced by supplying $\mathrm{CO}_{2}$ at the rate of $75 \mathrm{~mL} / \mathrm{min}$ and gradually increasing the flow of $\mathrm{H}_{2}$ to the anode in steps as follows: $10 \mathrm{~mL} / \mathrm{min}, 20 \mathrm{~mL} / \mathrm{min}, 50 \mathrm{~mL} / \mathrm{min}$, $100 \mathrm{~mL} / \mathrm{min}, 150 \mathrm{~mL} / \mathrm{min}$ and $250 \mathrm{~mL} / \mathrm{min}$. Between each step sufficient time intervals were allowed for the cell voltage to stabilize. At the cathode the air flow was maintained at $2000 \mathrm{~mL} / \mathrm{min}$. After reduction of the anode the I-V characteristics of the cell were drawn and then the cell was operated at a constant current density of $285 \mathrm{~mA} / \mathrm{cm}^{2}$ while the cell voltage was monitored.

During the first test the operating temperature of the cell was maintained at $900{ }^{\circ} \mathrm{C}$ and the long-term performance without salt contamination was measured at a constant current load of $285 \mathrm{~mA} / \mathrm{cm}^{2}$ for $850 \mathrm{~h}$. The next test was conducted on a new cell with the same operating conditions with salt introduced to the cathode at $1 \mathrm{ppm}$. The SEM images and I-V characteristics of these two cells were then, as mentioned, compared with a third, reference, cell operated for a short time, namely $12 \mathrm{~h}$, without any current load at $900{ }^{\circ} \mathrm{C}$.

\subsubsection{Oxygen Depletion Tests}

The performance of an SOFC cathode under decreasing partial pressure of oxygen $\left(\mathrm{P}_{\mathrm{O}_{2}}\right)$ in the oxidant air supplied to the cathode was studied and analysed. This experiment was performed to evaluate the effect on the cell performance if it is coupled in series with other cells, the oxygen concentration reducing in successive stages, or the supply of oxygen in air is reduced, e.g., due to leakage of a seal or is stopped for short periods, e.g., due to air supply interruption.

The experiments were conducted at three different cell temperatures of $800{ }^{\circ} \mathrm{C}, 850{ }^{\circ} \mathrm{C}$ and $900{ }^{\circ} \mathrm{C}$ and the effects were characterized by I-V curves. For planar SOFCs with LSM electrodes, the normal operating temperature range is between $800^{\circ} \mathrm{C}$ and $1000^{\circ} \mathrm{C}$, hence we chose to conduct the experiments in this range.

Heating of the cell for the testing was carried out under a constant supply of air at $200 \mathrm{~mL} / \mathrm{min}$ at the cathode side. The cell was heated to $850{ }^{\circ} \mathrm{C}$ at a rate of $1.6^{\circ} \mathrm{C} / \mathrm{min}$. Heating and cooling rates were determined in such a way as to prevent cracking in the cell.

Reduction of the cell was carried out at $850^{\circ} \mathrm{C}$ at a constant supply of $\mathrm{CO}_{2}$ of $75 \mathrm{~mL} / \mathrm{min}$ and a stepwise addition of $\mathrm{H}_{2}$ of $10,20,50,100,150,250 \mathrm{~mL} / \mathrm{min}$ at the fuel side. Oxidant air was supplied at the rate of $600 \mathrm{~mL} / \mathrm{min}$ to the cathode side.

A sequence of measurements at a given cathode oxygen concentration included a measurement of the OCV with no external current applied and a series of measurements of the voltage over the cell at 
step-wise increasing external current (each time allowing a suitable time interval to reach steady-state), until the current exceeded a previously chosen maximum value of $3.5 \mathrm{~A}$ or the voltage over the cell decreased below a chosen minimum value of $0.5 \mathrm{~V}$.

The oxygen concentration at the cathode was decreased step-wise by decreasing the oxygen flow-and increasing the nitrogen flow to make the total flow constant-in steps of $80 \mathrm{~mL} / \mathrm{min}$. The initial flow parameters are shown in Table 1. Also here time was allowed for establishment of steady-state after each change in flowrates.

Table 1. Initial flow parameters for the oxygen depletion tests.

\begin{tabular}{lllll}
\hline Cathode: & Air & $600 \mathrm{~mL} / \mathrm{min}$ & $\mathrm{N}_{2}$ & $0 \mathrm{~mL} / \mathrm{min}$ \\
\hline Anode: & $\mathrm{H}_{2}$ & $250 \mathrm{~mL} / \mathrm{min}$ & $\mathrm{CO}_{2}$ & $75 \mathrm{~mL} / \mathrm{min}$ \\
\hline
\end{tabular}

All measurements were performed with a fuel composition of $\mathrm{CO}_{2}=75 \mathrm{~mL} / \mathrm{min}$ and $\mathrm{H}_{2}=250 \mathrm{~mL} / \mathrm{min}$. This rate avoids the depletion of fuel influencing the I-V measurements at higher fuel utilisation rates. A comparison of the electrochemical performance at different $\mathrm{P}_{\mathrm{O}_{2}}$ supplied to the cathode of the single cell and at different operating temperatures $\left(800,850,900{ }^{\circ} \mathrm{C}\right)$ are analysed by the I-V characteristics. The I-V curve was measured by increasing the current load starting from $0 \mathrm{~A}$, incrementing step-wise with $0.25 \mathrm{~A} / \mathrm{cm}^{2}$, until a current load of $3.5 \mathrm{~A} / \mathrm{cm}^{2}$ was reached or the cell voltage dropped below $0.5 \mathrm{~V}$.

The initial oxidant air composition had $21 \%$ oxygen and $79 \%$ nitrogen and the total flow rate was $600 \mathrm{~mL} / \mathrm{min}$. The oxygen in air was reduced in steps by reducing the supply of air and adding nitrogen in such a way as to keep the total flow constant at $600 \mathrm{~mL} / \mathrm{min}$. After completing one step, the flow parameters for air and nitrogen were changed automatically.

\section{Results and Discussion}

\subsection{Salt Degradation Tests}

\subsubsection{Short-Term Salt Degradation Tests}

The effect of salt contamination on the cell operating at $850{ }^{\circ} \mathrm{C}$ is shown in Figure 4 . This cell was initially operated without any salt contamination for $70 \mathrm{~h}$ (marked initial in Figure 4) and the cell voltage remained almost unchanged during this period. Also after salt had been introduced to the cathode at a concentration of $1.6 \mathrm{ppm}$ for $14 \mathrm{~h}$ (stage 2 in the figure), the performance of the cell remained almost the same as it was without contamination.

After the salt contamination had been increased to $250 \mathrm{ppm}$ for $50 \mathrm{~h}$, significant degradation in the performance of the cell was seen (stage 3 in the figure). The voltage dropped by $25 \mathrm{mV}$ at $325 \mathrm{~mA} / \mathrm{cm}^{2}$. New salt crystals of $0.512 \mathrm{~g}$ were then added to the feed pipe and charged to the cathode at the rate of 250 ppm for $18 \mathrm{~h}$.

The microstructure of the cell was examined using SEM, see Figure 5 for an SEM image of the whole cell cross-section, and traces of $\mathrm{Na}$ present at the surface of the cathode and diffusion of $\mathrm{Na}$ into the cathode was analysed by performing X-ray Diffraction (XRD) associated with the SEM on the cathode cross-section. 


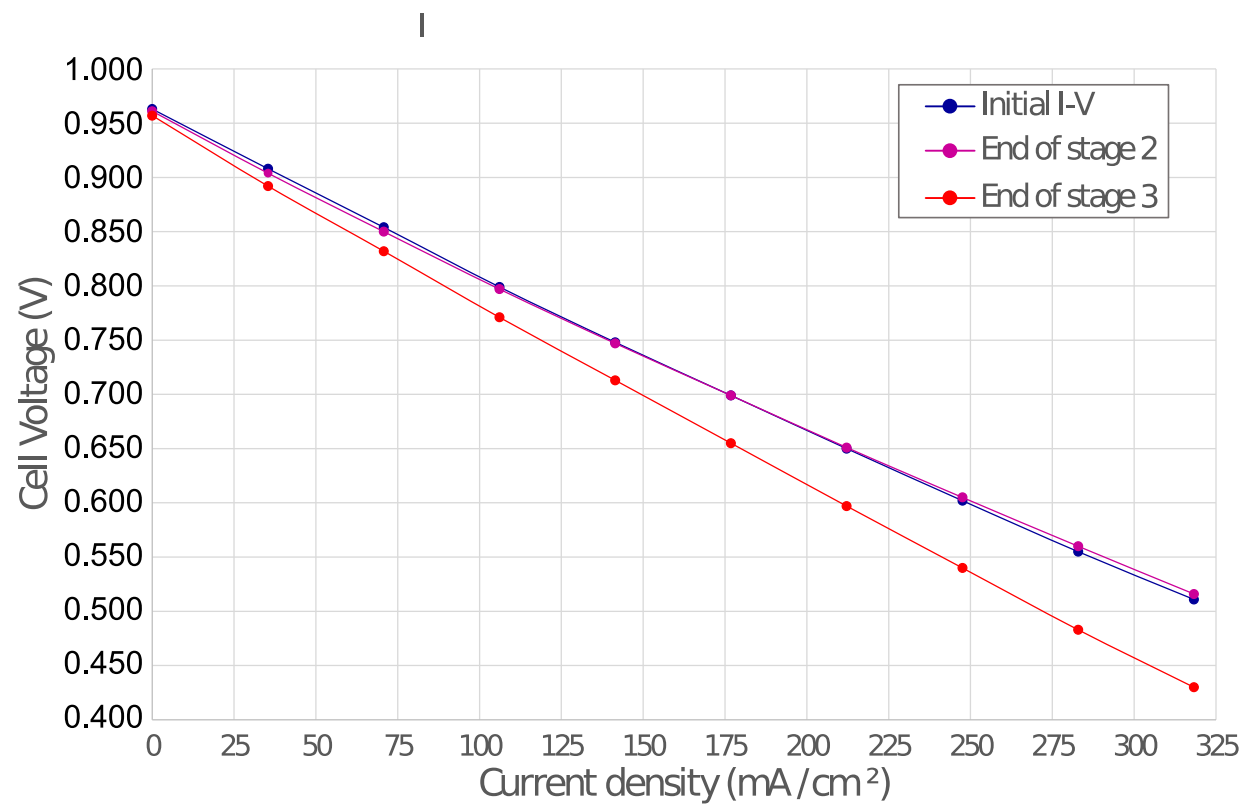

Figure 4. The performance of the cell at different stages of the short-term degradation test: Stage $\mathbf{1}$ is the I-V of the cell having been operated for a period of $50 \mathrm{~h}$ without any salt contamination. Stage $\mathbf{2}$ is the I-V for the cell after having been operated with salt contamination for $14 \mathrm{~h}$ at the rate of $1.6 \mathrm{ppm}$. Stage 3 is the I-V for the cell after having been operated with increased salt contamination of $250 \mathrm{ppm}$ for $50 \mathrm{~h}$.

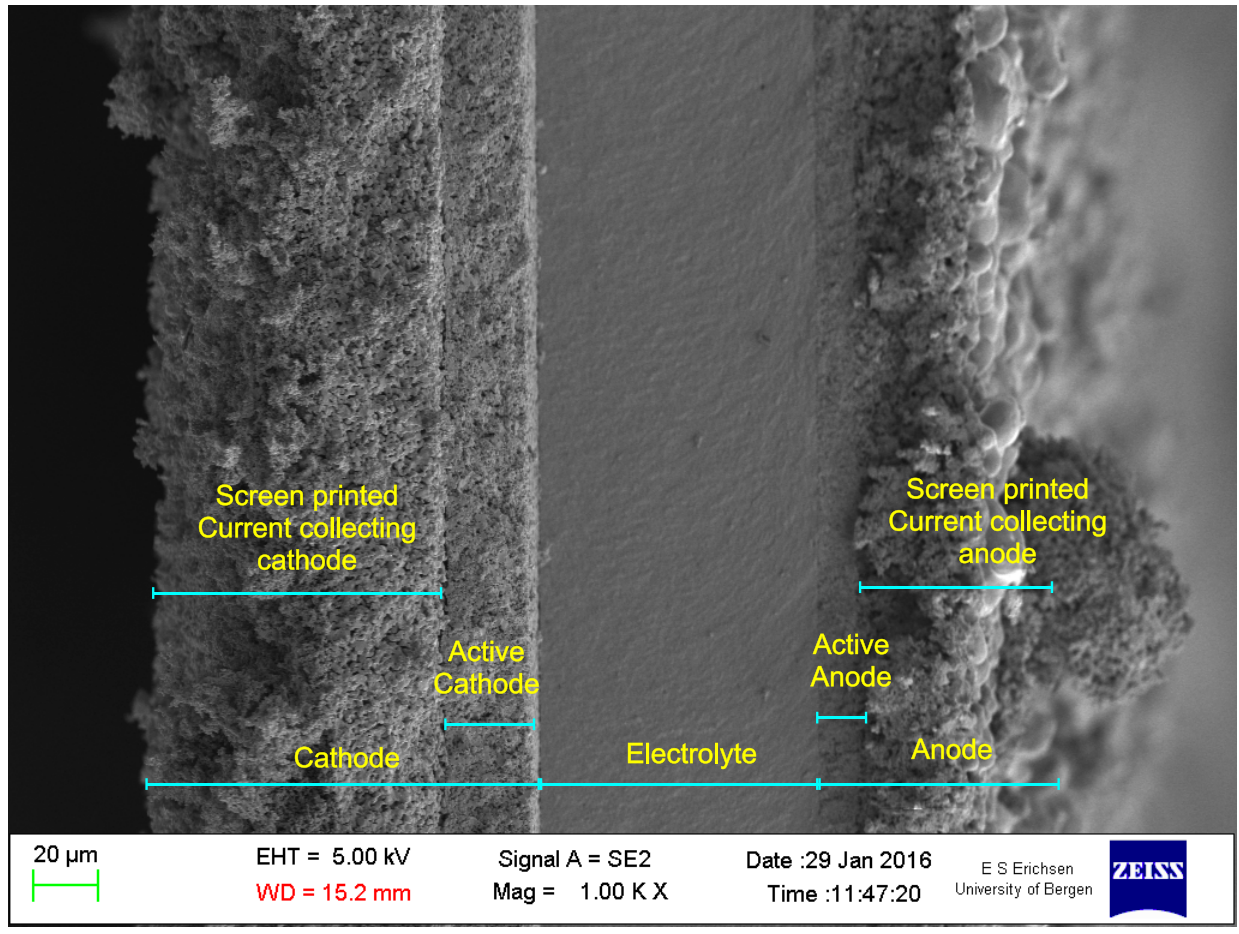

Figure 5. Cross-sectional SEM image of the entire cell operated at $850{ }^{\circ} \mathrm{C}$, after a short-term degradation test.

The points at which the XRD was done are shown in Figure 6 and the result of the XRD analyses is shown in Figure 7, the concentrations measured are shown in Table 2. It is clear that the concentrations of $\mathrm{Na}$ in weight \% increase gradually from point 2 to point $5(1.06 \%)$ and some traces of $\mathrm{Na}$ can be found in the cathode functional layer. 
Table 2. Mass \% of elements.

\begin{tabular}{lcccccccccccc}
\hline pt. & B-K & C-K & O-K & Na-K & Al-K & Ca-K & Sc-K & Mn-K & Ni-K & Sr-L & Zr-L & La-L \\
\hline 1 & & 7.77 & 7.47 & 0.00 & 15.76 & & & 3.75 & 45.36 & & 8.50 & 11.38 \\
2 & & 1.85 & 11.67 & 0.25 & 1.90 & 0.32 & & 28.72 & 5.30 & 7.66 & & 42.33 \\
3 & & 1.36 & 10.66 & 0.26 & 0.45 & 0.27 & & 30.36 & 4.04 & 7.77 & & 44.82 \\
4 & & 1.56 & 13.64 & 0.44 & & & & 30.16 & 1.23 & 8.89 & & 30.26 \\
6 & & 2.03 & 17.86 & 0.91 & & & & 28.66 & & 8.99 & & 42.04 \\
7 & 0.65 & 2.47 & 27.27 & 0.30 & & & 3.55 & 12.36 & & 2.64 & 34.78 & 15.99 \\
8 & 0.85 & 2.88 & 29.39 & 0.28 & & & 2.83 & 10.94 & 0.64 & 2.05 & 34.99 & 15.15 \\
\hline
\end{tabular}

The SEM images obtained from the cell operated with salt contamination for a short term duration do not show any sign of delamination. This indicates that the cell mechanically tolerates salt contamination for a short duration. However, as shown by Figure 4 the cell voltage dropped considerably, without us being able to say categorically why this should be so.

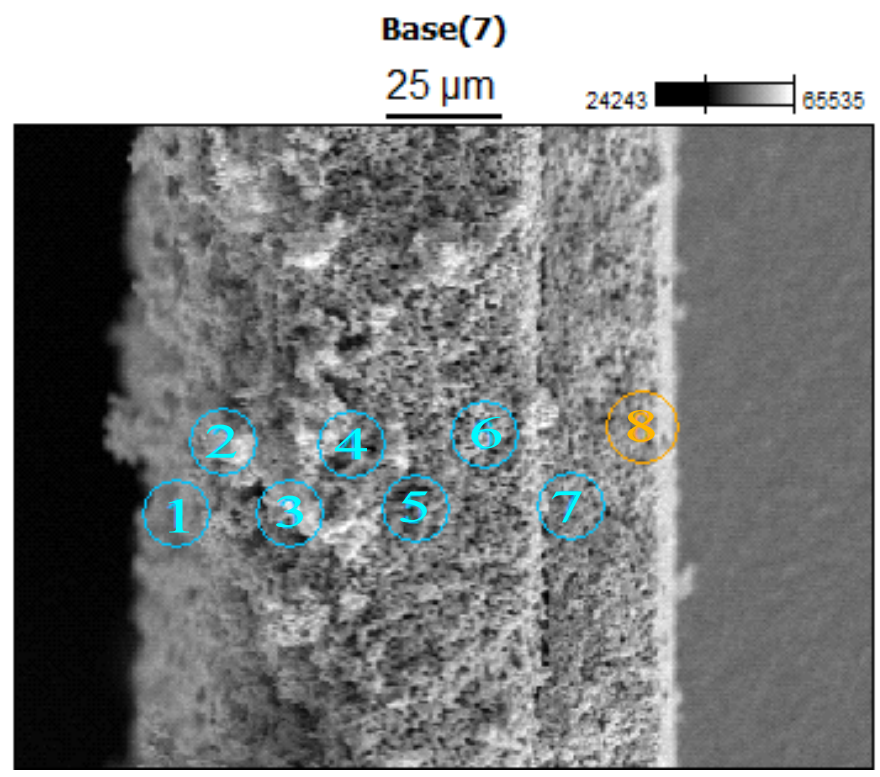

Figure 6. Cross-sectional SEM image of the cathode showing the points at which X-ray diffraction was performed to analyse the components present.

We thus do not see any sudden degradation of the cell performance upon introduction of the impurity, like that seen by Cheng et al. [6] for some of the impurities that they tested, but rather a gradual decrease in the performance as also seen by them in some of their tests. This is confirmed by the long-term tests discussed below.

The results of the short-term tests are qualitatively similar to those obtained by Liu et al. [3], but in contrast to them we did find more reduction in cell performance, although still moderate, with the higher salt concentration in the cathode feed than with the lower concentration. 


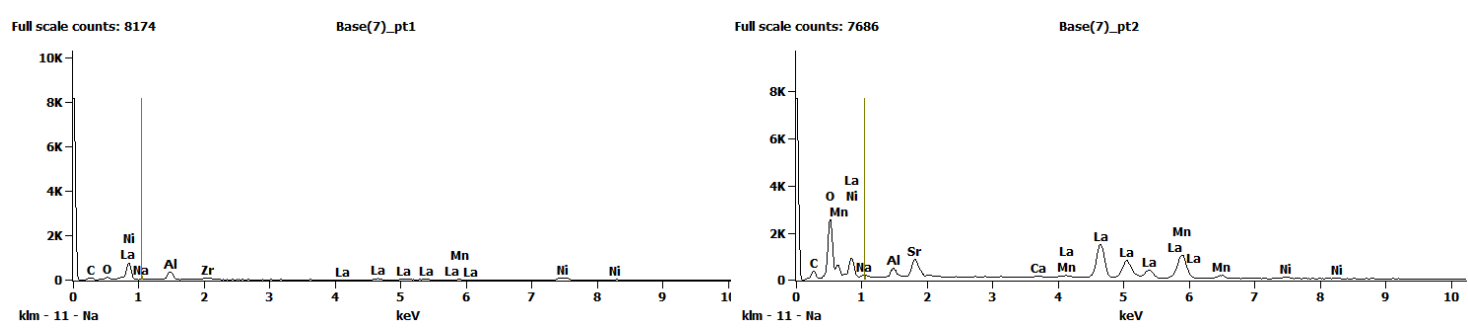

(a) Point 1

(b) Point 2

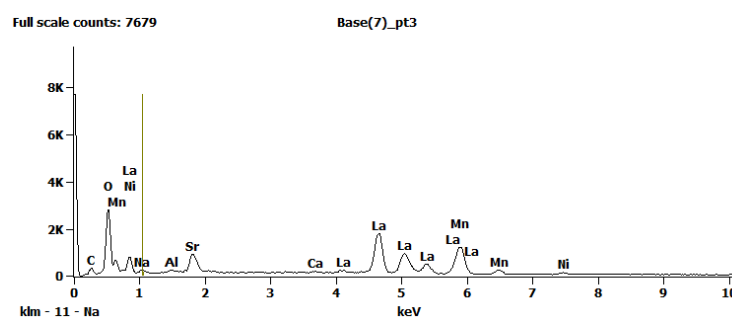

(c) Point 3

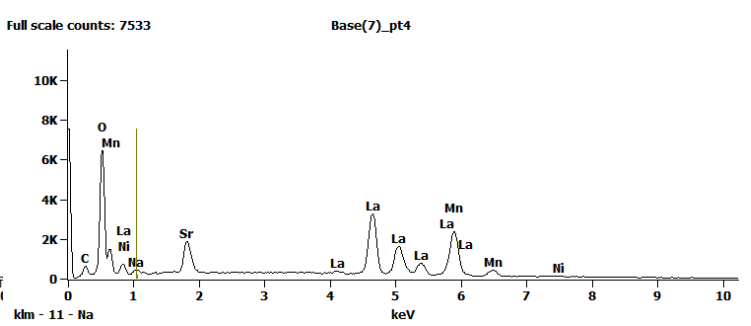

(d) Point 4

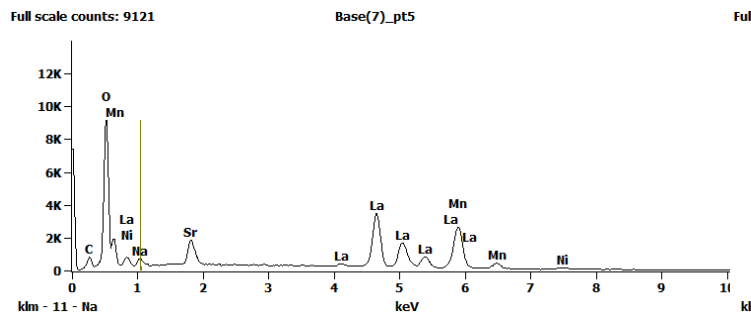

(e) Point 5

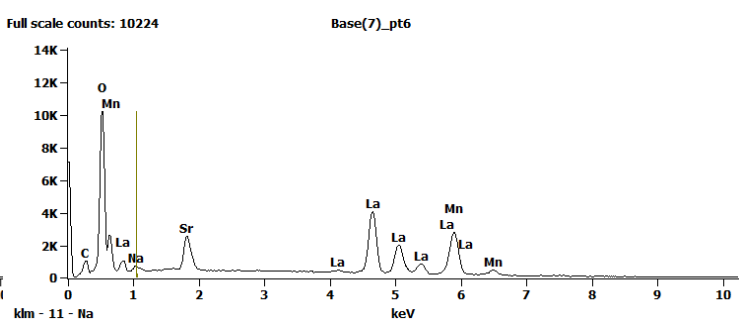

(f) Point 6

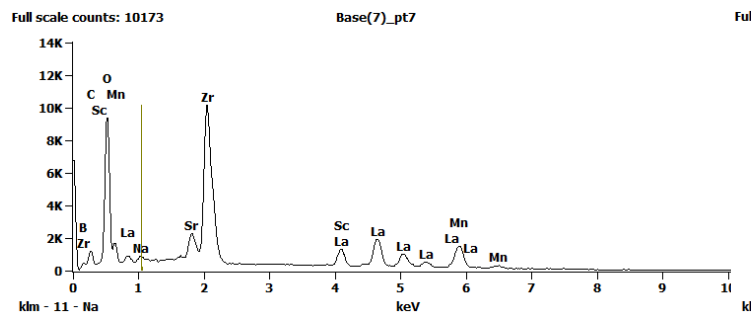

(g) Point 7

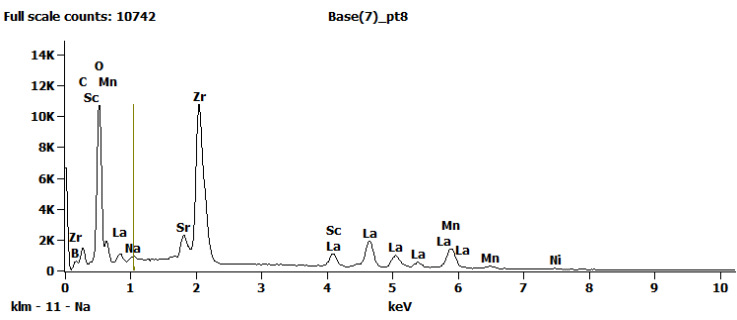

(h) Point 8

Figure 7. X-ray Diffraction (XRD) patterns of LSM current collecting layer in the cathode and the ScSZ/LSM cathode electro-catalytic layer.

\subsubsection{Long-Term Salt Degradation Tests}

The long-term degradation effects on a single cell are shown in Figure 8. The degradation curve for a cell without any salt contamination at $900{ }^{\circ} \mathrm{C}$ shows that there was an initial degradation from $0.8375 \mathrm{~V}$ to $0.825 \mathrm{~V}(12.5 \mathrm{mV})$ taking place over a period of $40 \mathrm{~h}$. After this, the cell voltage stabilised and there was a drop of only $10 \mathrm{mV}$ during the next $460 \mathrm{~h}$ of operation. After an initial $550 \mathrm{~h}$ of operation, a bad contact was observed in the current-collecting wire from the anode. For this reason, the cell had to be cooled down and, after fixing the connections, the cell was operated again. During this period the anode had oxidised and the anode redox reactions started to take place when the cell was operated again. Hence, there was a drop in cell voltage at around $560 \mathrm{~h}$ (23rd day of cell operation). The total drop in cell voltage over $850 \mathrm{~h}$ was $25 \mathrm{mV}$, as observed from the degradation curve.

The performance of the cell with salt contamination at $900{ }^{\circ} \mathrm{C}$ was studied in the second test. Here a continually decreasing performance of the cell was observed and the cell voltage dropped by $200 \mathrm{mV}$ over a period of about $660 \mathrm{~h}$ (27.5 days). During the operation of this test with salt contamination 
for a long duration, a bad contact was observed at the voltage measurement probe of the anode side. The cell operation was limited to $660 \mathrm{~h}$ due to time constraints.

Figure 9 shows the initial and final performance of the two cells with and without salt contamination. The curves marked initial indicates the baseline I-V characteristics observed immediately after reducing the anode. The curves marked final show the characteristics of the cell after operating it under a steady-state current load for a long time (respectively $850 \mathrm{~h}$ and $660 \mathrm{~h}$ without and with salt contamination). The initial baseline I-V curves for both the cells show that their performance before the testing were identical.

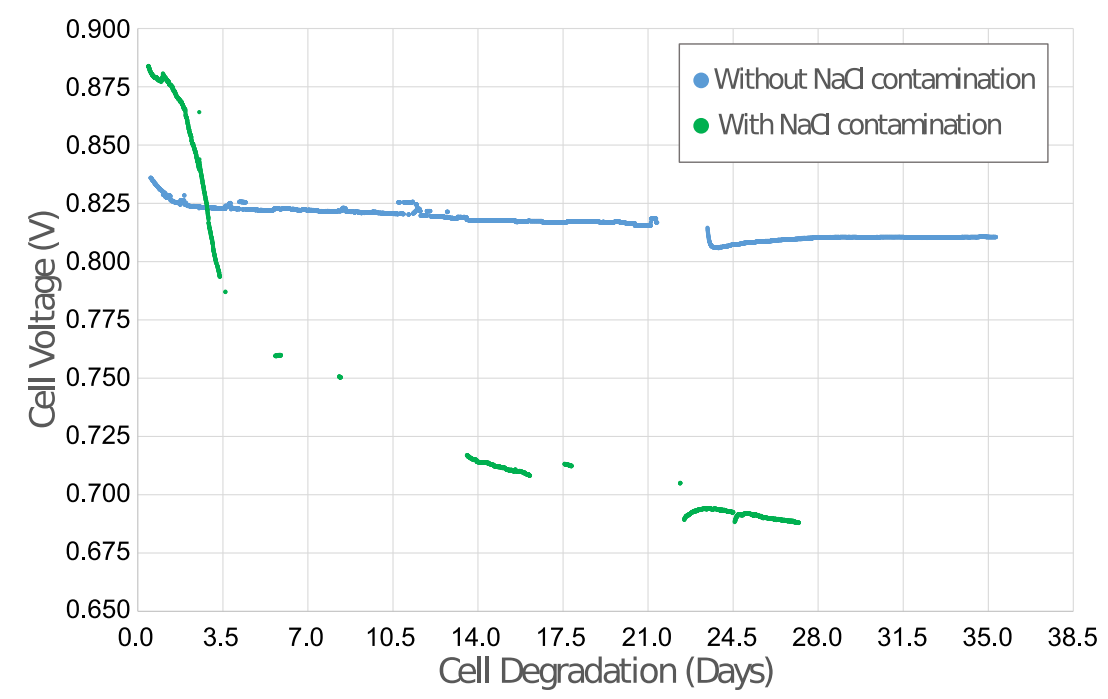

Figure 8. Long-term degradation of the single cell at $900{ }^{\circ} \mathrm{C}$ and a current density of $285 \mathrm{~mA} / \mathrm{cm}^{2}$ without salt contamination and with $1 \mathrm{ppm}$ of continuous salt contamination.

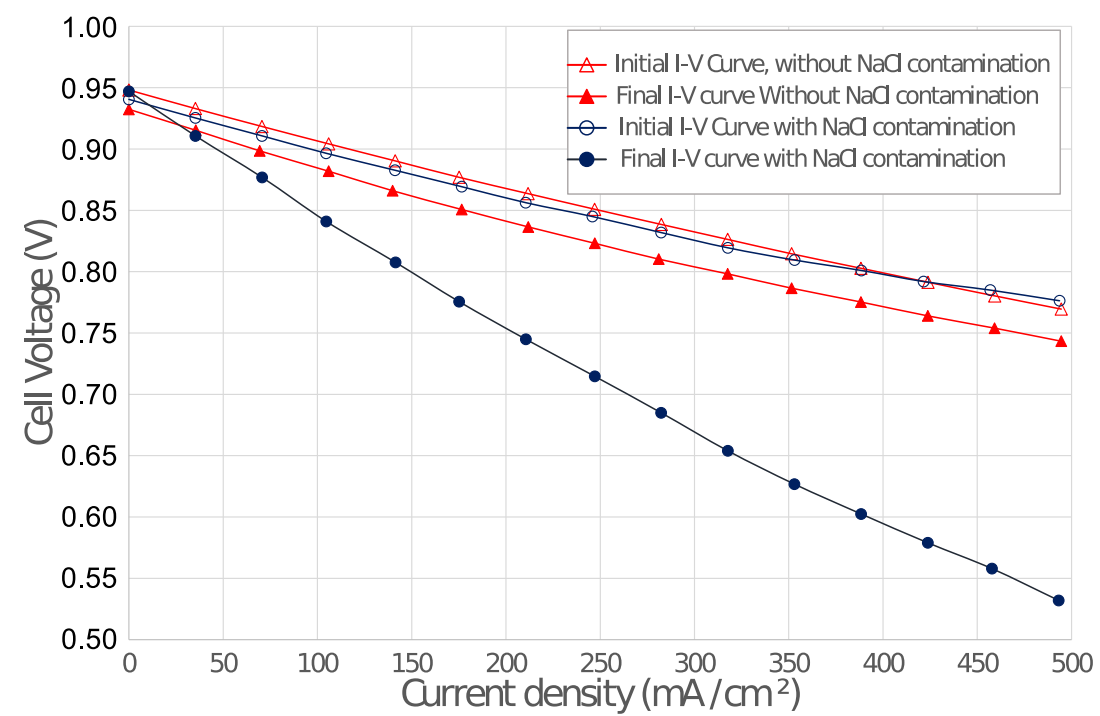

Figure 9. The baseline I-V curves and final I-V curves of the cell at $900{ }^{\circ} \mathrm{C}$, without salt contamination for $850 \mathrm{~h}$ and with salt contamination of $1 \mathrm{ppm}$ for $660 \mathrm{~h}$.

The I-V curves obtained after $850 \mathrm{~h}$ of cell operation without salt contamination exhibited a drop of $25 \mathrm{mV}$ cell voltage when compared to the initial baseline curve.

The final I-V curve obtained after long-term testing with salt contamination to the cell shows a large increase in ohmic losses when compared to the loss seen in the final I-V curve without salt contamination. At a current load of $500 \mathrm{~mA} / \mathrm{cm}^{2}$, the drop in cell voltage is about $200 \mathrm{mV}$. 
When searching for the reason for the severe drop in long-term cell performance, the microstructure of the cell was studied using SEM. The results of this are shown in Figure 10.

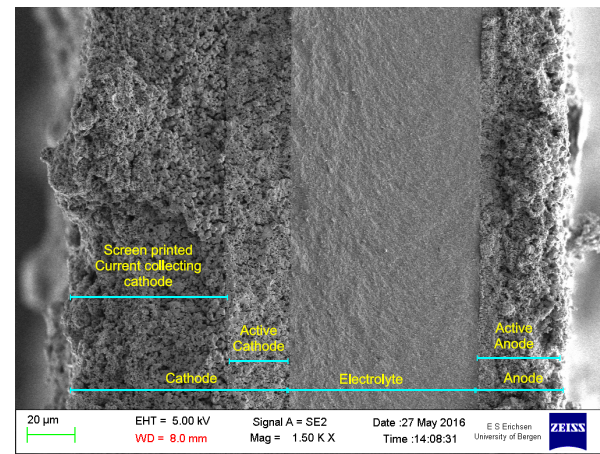

(a)

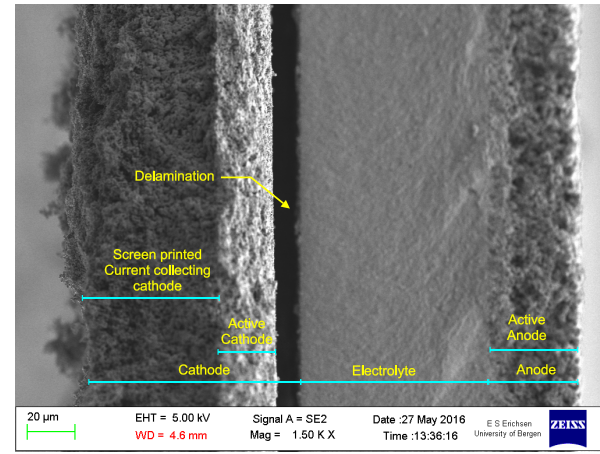

(c)

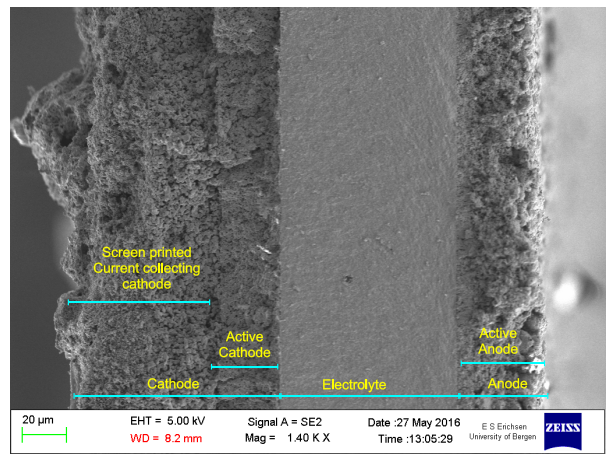

(b)

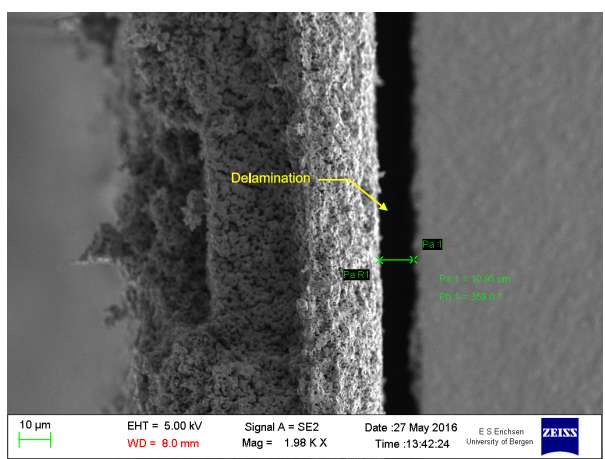

(d)

Figure 10. Cross sectional SEM images of the cells after long-term testing at $900{ }^{\circ} \mathrm{C}$. (a) Shows the cell in its initial state. (b) shows the cell that has been operated for $850 \mathrm{~h}$ without salt contamination. (c) shows the cell after operation with salt contamination (at $1 \mathrm{ppm}$ ) for $660 \mathrm{~h}$, the cell can be seen to have delaminated leading to severe and irreversible degradation. (d) shows a detail of the delamination.

The SEM images show that there is no delamination of the cell operated without salt contamination, while the cell operated with salt contamination develops delamination. This is clearly the reason that the cell operated for a long term without any salt contamination shows better performance than the cell operated with salt contamination.

Liu et al. [3] did not perform long-term tests and could therefore not have found the same severe reduction in cell performance due to delamination as we found in this study.

\subsection{Oxygen Depletion Tests}

The I-V tests to study the effect of oxygen depletion in the air supply to the cathode have three main elements:

- Characterising the open circuit voltage (OCV) of the cell to ensure that there was very little cross-leak or electronic conductivity in the electrolyte and that the components were sealed properly [17].

- Examining the shape of the I-V curve at a specific temperature in order to determine the amount of the polarizations: activation, ohmic and (importantly) concentration polarization at the cathode due to varying oxygen partial pressure at three temperatures $\left(800^{\circ} \mathrm{C}, 850^{\circ} \mathrm{C}\right.$ and $\left.900{ }^{\circ} \mathrm{C}\right)$.

- Studying the electrochemical performance of the cell at high current density and at reducing partial pressure of oxygen.

We would expect that the I-V characteristics of the SOFC will show that the ohmic loss increases almost linearly as the current density increases. At a relatively large current density, the potential 
of the cell would be expected to decrease more rapidly and in a non-linear fashion, indicating the dominance of concentration polarization. A high current density requires fast consumption of the reactant gas (oxygen) and also fast exhaustion of the products, possibly exceeding the gas transport rate in the electrode, both due to the oxygen-depleted diffusion film adjacent to the active sites and due to transport limitation in the fine pores [18,19].

The equation for the EMF of the cell from fundamental thermodynamics is:

$$
E=E^{\circ}+\frac{R T}{2 F} \ln \left(\frac{\alpha \cdot \beta^{\frac{1}{2}}}{\delta}\right)+\frac{R T}{4 F} \ln \left(\frac{P}{P^{\circ}}\right)
$$

where, if the gaseous reactants and products behave ideally, which is probably a good approximation at the low pressures used here, $\alpha, \beta$ and $\delta$ are the mole fractions of $\mathrm{H}_{2}, \mathrm{O}_{2}$ and $\mathrm{H}_{2} \mathrm{O}$, respectively.

The effect of the oxygen concentration on the EMF of the cell can thus be expressed:

$$
E=E_{0}+\frac{R T}{4 F} \ln \beta
$$

or the effect on the cell voltage:

$$
\Delta V=\frac{R T}{4 F} \ln \beta
$$

where $\beta$ is the mole fraction of $\mathrm{O}_{2}$

As mentioned, we can roughly distinguish between ohmic polarization (OP) and concentration polarization $(\mathrm{CP})$ from the shape of the I-V curves.

Figures 11 and 12 show the I-V curves for cells working at $800^{\circ} \mathrm{C}$ and $850^{\circ} \mathrm{C}$, respectively. The $\mathrm{I}-\mathrm{V}$ curve is first determined at $21 \%$ oxygen to establish a reference curve. Keeping all the operating parameters constant, it is clear that the OP, which is the slope of the I-V curve, is higher in the cell operating at $800{ }^{\circ} \mathrm{C}$ and decreases with increasing temperature (Figure 13). This agrees very well with the literature that the oxygen ion conductivity through the 3YSZ electrolyte increases with temperature in the range $600{ }^{\circ} \mathrm{C}$ to $1000{ }^{\circ} \mathrm{C}[20]$.

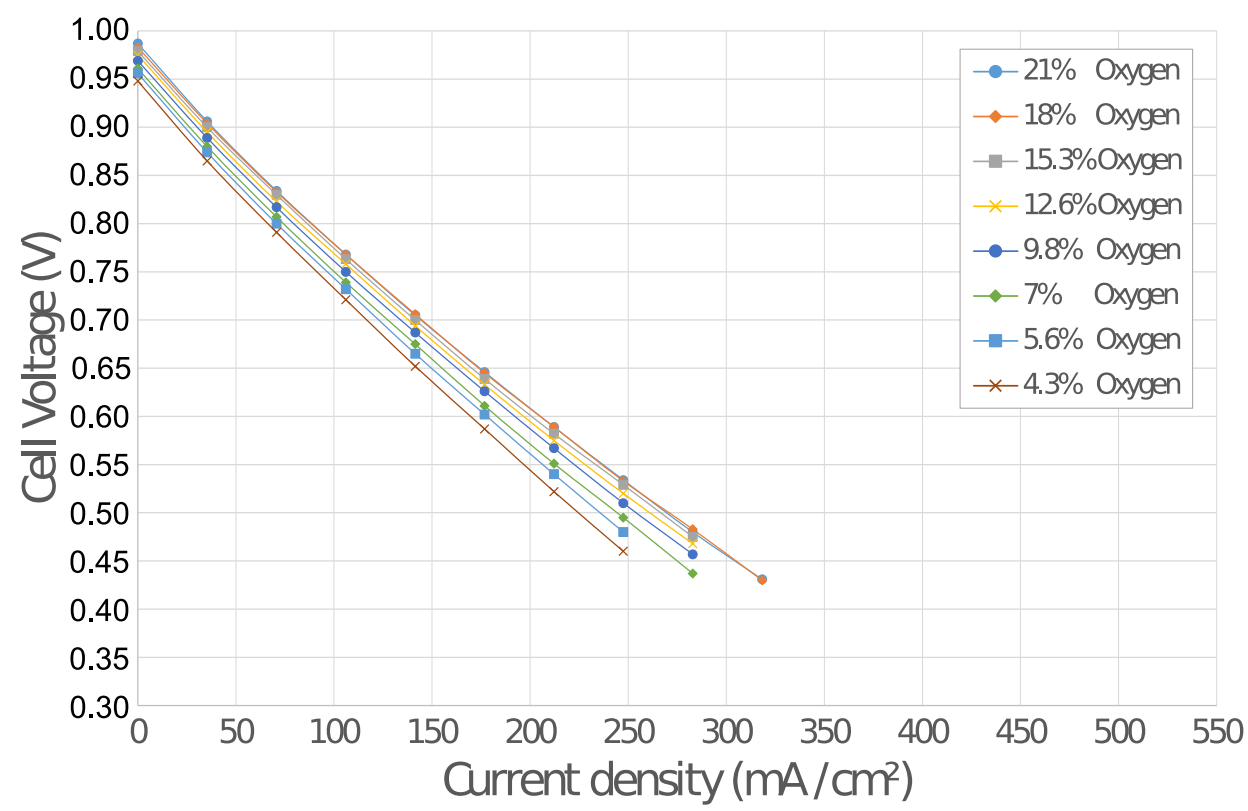

Figure 11. The performance of the cell at $800{ }^{\circ} \mathrm{C}$ with decreasing partial pressure of oxygen. The ohmic losses are high and the drop in voltage is significant as the partial pressure of oxygen at the cathode decreases. 


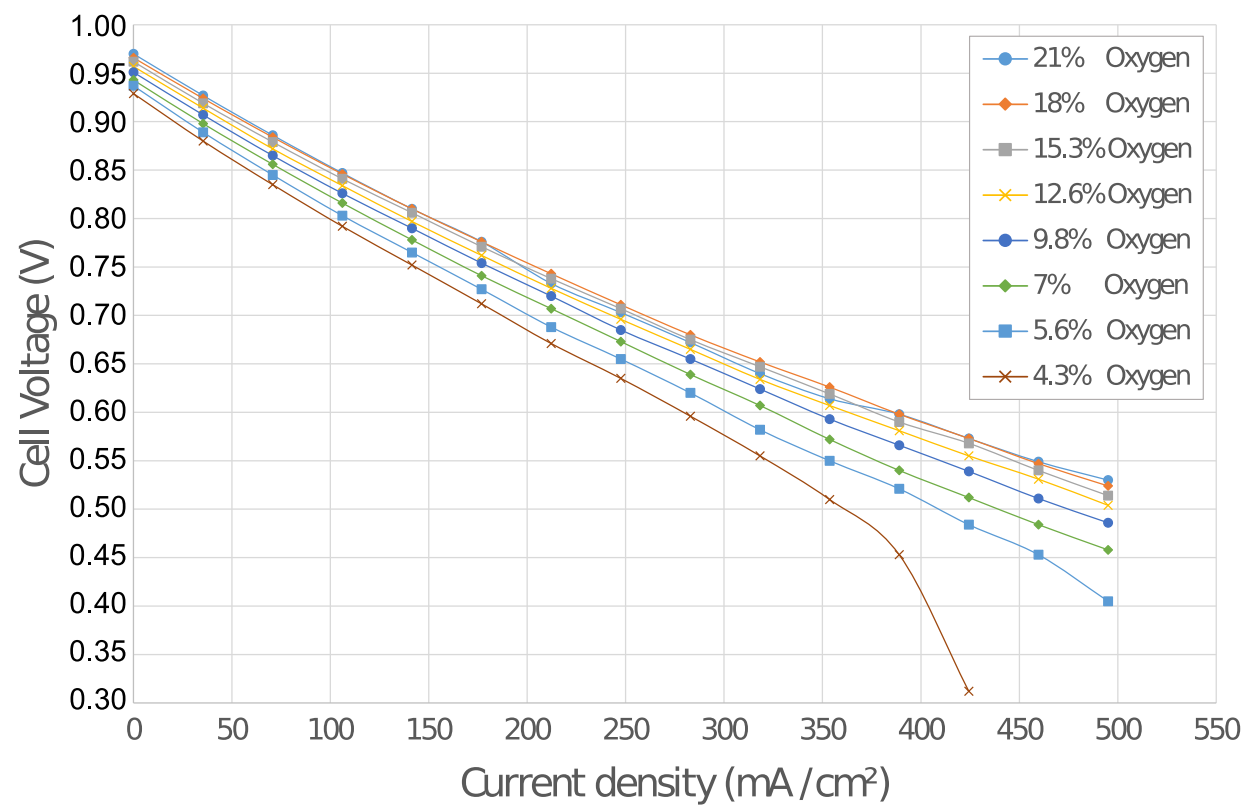

Figure 12. The performance of the cell at $850{ }^{\circ} \mathrm{C}$ with decreasing oxygen partial pressure. The performance decreases for lower partial pressures, under $12.6 \%$ oxygen. However, the loss is less than that at $800{ }^{\circ} \mathrm{C}$.

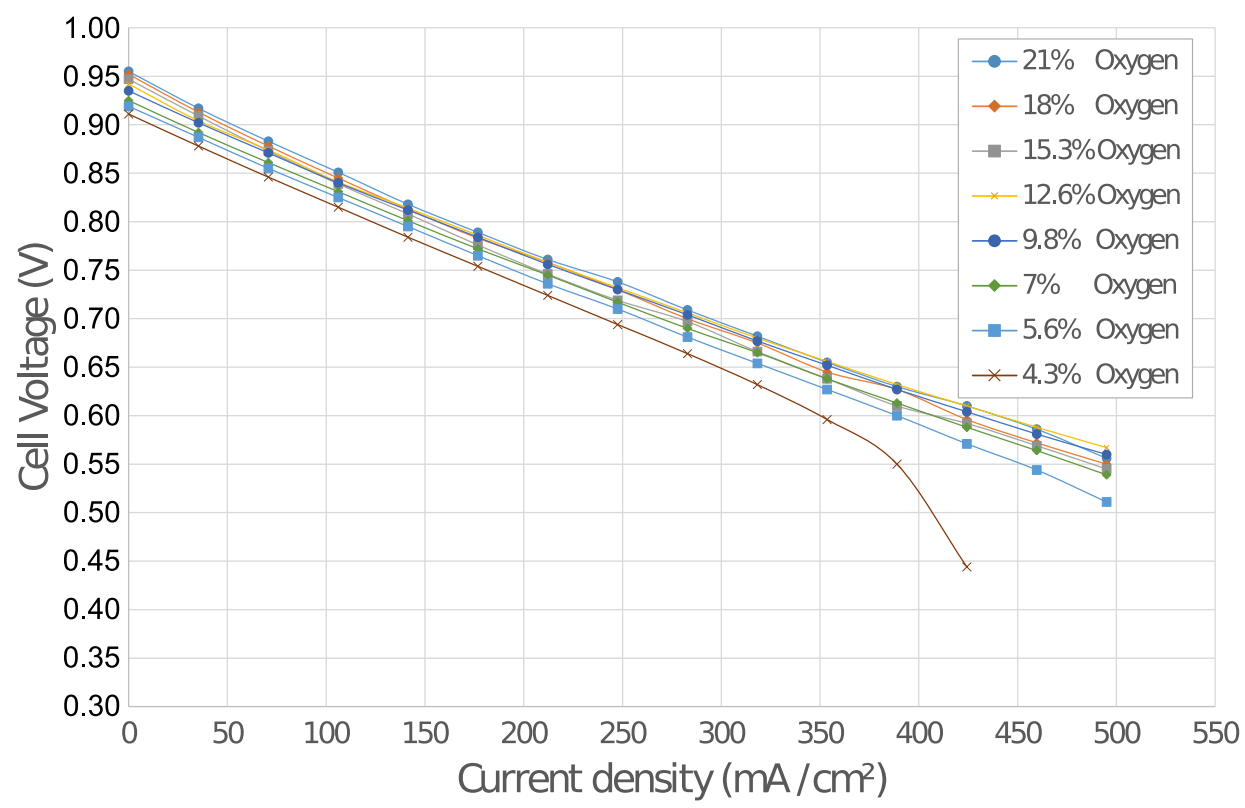

Figure 13. The performance of the cell operating at $900{ }^{\circ} \mathrm{C}$ with decreasing partial pressure of oxygen-At $900{ }^{\circ} \mathrm{C}$, the performance of the cell is better than that of the cells operated at $800{ }^{\circ} \mathrm{C}$ and $850{ }^{\circ} \mathrm{C}$. But its performance decreases for very low partial pressure of oxygen, smaller than $5.6 \%$ oxygen.

A comparison of $\mathrm{CP}$ at $850^{\circ} \mathrm{C}$ and $900^{\circ} \mathrm{C}$ at lower partial pressures of oxygen in the feed supplied to the cathode is shown in Figure 14. This plot indicates that as the operating temperature of the cell is increased, the effect of decreasing partial pressure is reduced. However, the current densities at these higher temperatures could be made so high that the effect of $\mathrm{CP}$ could be seen to set in at the lowest oxygen concentrations. 


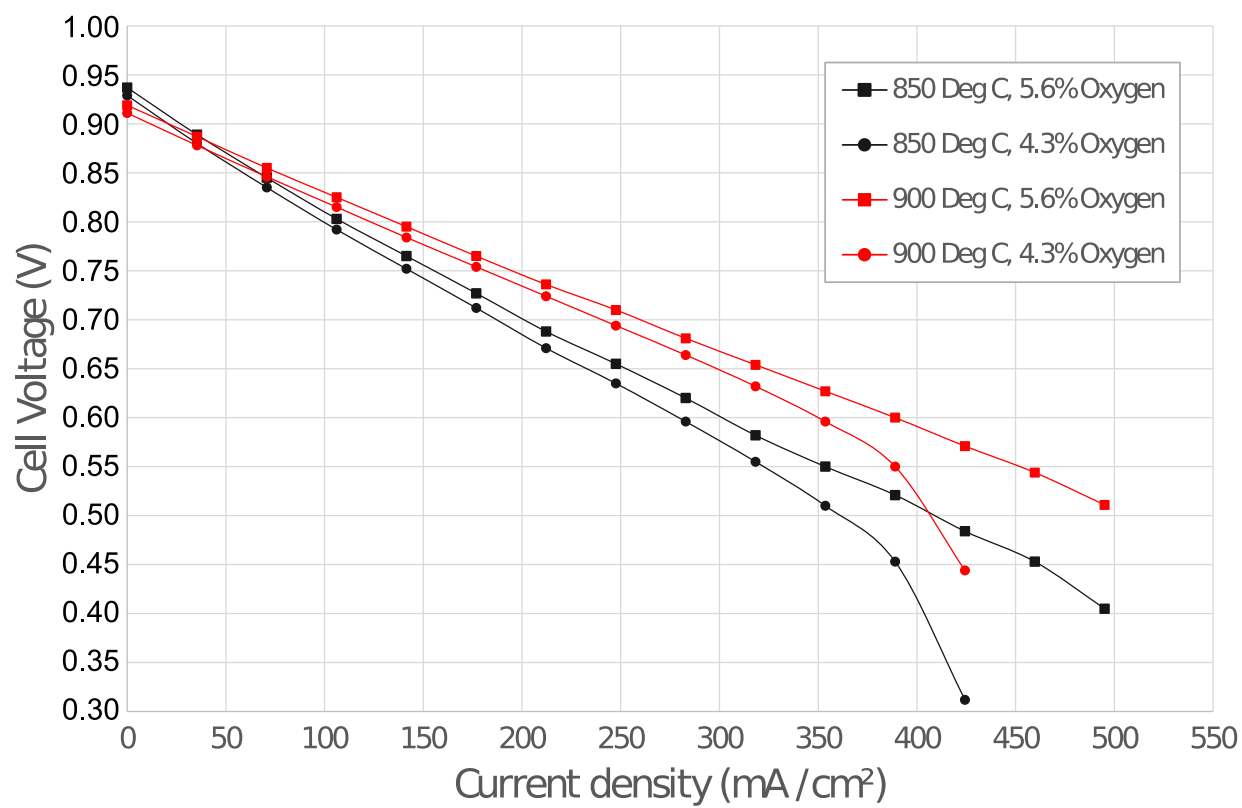

Figure 14. I-V curves for the two highest operating temperatures at the two lowest oxygen partial pressures. This shows that as the operating temperature of the cell is increased, the effect of decreasing partial pressure of oxygen is mitigated.

Figure 15 gives information about the cell performance at the three different temperatures and shows voltage-current density and power-current density characteristics, from which it can be seen that at $900{ }^{\circ} \mathrm{C}$ the cell has the higher power density of $280 \mathrm{~mW} / \mathrm{cm}^{2}$. This is consistent with the literature [21,22].

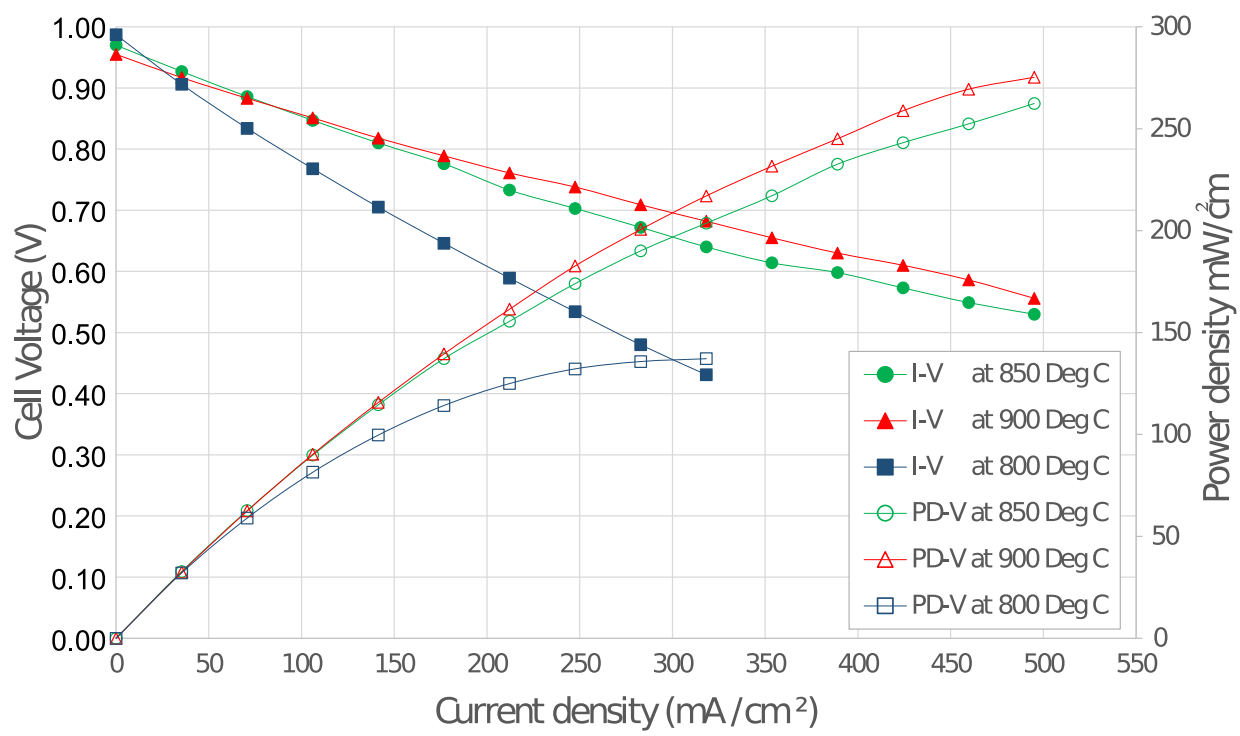

Figure 15. Voltage-current density and power-current density plots of the planar SOFC using air as oxidant-While using air as an oxidant ( $21 \%$ oxygen), it is observed that at low current densities very little difference in the performances of the cells operating at $850{ }^{\circ} \mathrm{C}$ and at $900{ }^{\circ} \mathrm{C}$ is observed. However, the cell operated at $800{ }^{\circ} \mathrm{C}$ exhibits very high ohmic losses.

Figure 16 shows the effect on the cells of carrying out the testing program. The figure shows I-V curves with $21 \%$ oxygen to the cathode both before and after the testing program. It is seen that the performance of the cell before carrying out the testing is not much different from the performance after the testing. Only at $850{ }^{\circ} \mathrm{C}$ the cell performance after the testing is significantly lower than its initial performance, which might indicate that the oxygen concentration to the cathode at this temperature, 
which was reduced to lower values $(4 \%)$ than at the other two temperatures, reached a critically low level during the experimental program whereby the cathode changed.

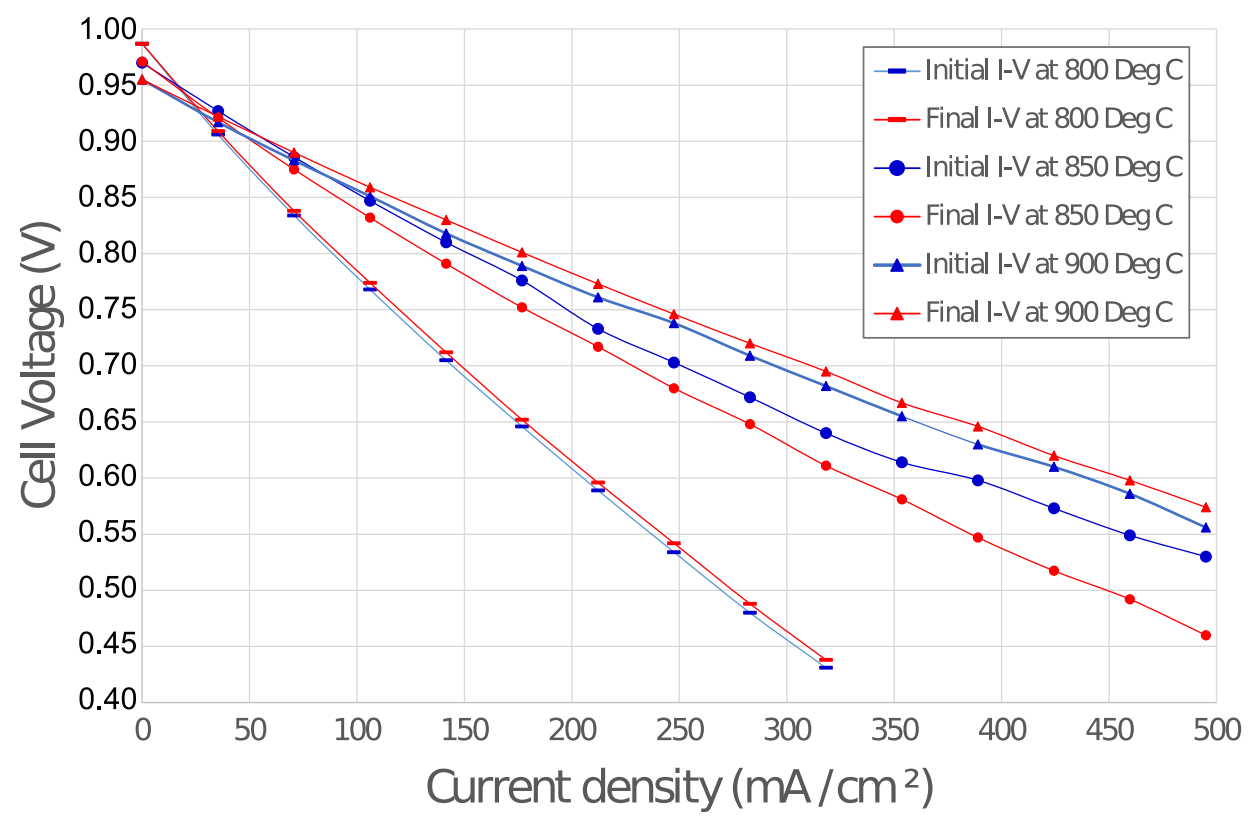

Figure 16. Voltage-current density comparison of the cell at different temperatures before and after the testing program-At $800^{\circ} \mathrm{C}, 850^{\circ} \mathrm{C}$ and at $900{ }^{\circ} \mathrm{C}$

\section{Further Discussion}

Figure 8 clearly shows that there were some equipment-related problems involved in the long-term tests, but although the curve is interrupted it does show a plausible continuous development in the cell performance as a function of time. We were able to show a clear difference in cells operated under the same conditions, apart from salt contamination in the flow to the anode, obtaining delamination only in the contaminated cell. It is important to carry out work to reproduce this result and to determine the reason for the delamination, perhaps testing whether expansion or contraction of one the cell components due to the presence of the salt in the feed to the cathode could cause the delamination.

The effect of the oxygen depletion in the cathode feed to cause concentration polarization is quite clear and the evidence shown in this paper is in accord with the classical I-V response to concentration polarization. The results for the different operating temperatures also demonstrate that these effects are reproducible.

\section{Conclusions}

- When the experiments were conducted without any salt contamination (both short-term and long-term), the final I-V curve of the cell was very close to that of the reference I-V characteristics observed immediately after reducing the anode showing that the testing method itself did not lead to significant degradation of the cell.

- During the short-duration tests, when salt crystals were introduced at the rate of $250 \mathrm{ppm}$, there was a drop in cell voltage by $25 \mathrm{mV}$. The SEM images after operating the cell with salt contamination for about $50 \mathrm{~h}$, did not show any sign of delamination, but salt is detectable in the cathode microstructure.

- During the long-duration testing, when salt was introduced at the rate of $1 \mathrm{ppm}$, a drop in cell voltage of $200 \mathrm{mV}$ was seen. The SEM images show that after operating the cell with salt contamination for about $660 \mathrm{~h}$, delamination had taken place. This indicates that there is a severe and irreversible degradation of the cell when salt pollutes the cathode for a long period. 
- As the operating temperature of the cell is increased from $800{ }^{\circ} \mathrm{C}$ to $900{ }^{\circ} \mathrm{C}$, the contribution to losses from ohmic polarization decreases. An electrolyte supported cell (YSZ) should therefore be operated at higher temperatures.

- The effect of decreasing oxygen partial pressure is more significant when the oxygen concentration is decreased below $12.6 \%$. The fall in cell voltage at higher current densities and very low oxygen concentration indicates the development of concentration polarisation.

- While using air as an oxidant $\left(21 \% \mathrm{O}_{2}\right)$, after operating the cell at reducing partial pressure, it is observed that the cell recovers immediately and there is very little difference in cell losses after testing when compared to before. When testing at $850{ }^{\circ} \mathrm{C}$ the cell was starved of oxygen to a greater extent $\left(4 \% \mathrm{O}_{2}\right)$ and in this case a significant drop in voltage due to the experimental program having been carried out was seen. The existence of a threshold low oxygen concentration, beyond which the cell appears to be damaged irreversibly, and the reason for the existence of such a threshold is worth further investigation.

Author Contributions: Conceptualization I.W., A.V., C.S. and A.C.H.; methodology, C.S.I.W.; software, N.T. and I.W.; validation, C.S., N.T. and A.C.H.; formal analysis, C.S. and N.T. and A.C.H.; investigation, N.T. and C.S.; resources, A.V. and I.W.; data curation, N.T. and C.S.; writing-original draft preparation, N.T. and A.C.H.; writing-review and editing, C.S. and A.C.H.; visualization, X.X.; supervision, C.S. and A.C.H.; project administration, C.S. and A.C.H.; funding acquisition, A.V. and I.W. All authors have read and agreed to the published version of the manuscript.

Funding: This research was funded by Gassnova grant number CHEOP-CC616060, and The Norwegian Research Council grant number CHEOP 245489/E30.

Acknowledgments: The authors would like to thank Gassnova and The Norwegian Research Council for funding this project and Shell and Statoil for helping as partners.

Conflicts of Interest: The authors declare no conflict of interest.

\section{References}

1. Ormerod, R.M. Solid oxide fuel cells. Chem. Soc. Rev. 2003, 32, 17-28. [CrossRef]

2. Nakajo, A.; Mueller, F.; Brouwer, J.; van Herle, J.; Favrat, D. Mechanical reliability and durability of SOFC stacks. Part I : Modelling of the effect of operating conditions and design alternatives on the reliability. Int. J. Hydrog. Energy 2012, 37, 9249-9268. [CrossRef]

3. Liu, R.; Wang, D.; Jing, L.; Wang, L.; Bai, X. NaCl Effect on SOFC Cathode. In Proceedings of the International Conference on Civil, Materials and Environmental Sciences (CMES 2015), London, UK, 14-15 March 2015.

4. Cayan, F.N.; Zhi, M.J.; Pakalapati, S.R.; Celik, I.; Wu, N.Q.; Gemmen, R. Effects of coal syngas impurities on anodes of solid oxide fuel cells. J. Power Sources 2008, 185, 595-602. [CrossRef]

5. Bao, J.; Krishnan, G.N.; Jayaweera, P.; Perez-Mariano, J.; Sanjurjo, A. Effect of various coal contaminants on the performance of solid oxide fuel cells: Part I. Accelerated testing. J. Power Sources 2009, 193, 607-616. [CrossRef]

6. Cheng, Z.; Zha, S.W.; Liu, M.L. Influence of cell voltage and current on sulfur poisoning behavior of solid oxide fuel cells. J. Power Sources 2007, 172, 688-693. [CrossRef]

7. K..; Adachi, S.; Shiratori, Y.; Itoh, K.; Sasaki, K. Poisoning of SOFC anodes by various fuel impurities. Solid State Ion. 2008, 179, 1427-1431. [CrossRef]

8. Horita, T.; Kishimoto, H.; Yamaji, K.; M. E. Brito, ME (Brito, M.E.; Xiong, Y.P.; Yokokawa, H.; Hori, Y.; Miyachi, I. Effects of impurities on the degradation and long-term stability for solid oxide fuel cells. J. Power Sources 2009, 193, 194-198. [CrossRef]

9. Yan, M.; Fu, P.; Chen, Q.Y.; Wang, Q.W.; Zeng, M.; Pandit, J. Electrical Performance and Carbon Deposition Differences between the Bi-Layer Interconnector and Conventional Straight Interconnector Solid Oxide Fuel Cell. Energies 2014, 7, 4601-4613. [CrossRef]

10. Xiong, Y.P.; Yamaji, K.; Horita, T.; Yokokawa, H.; Akikusa, J.; Eto, H.; Inagaki, T. Sulfur poisoning of SOFC cathodes. J. Electrochem. Soc. 2009, 156, B588-B592. [CrossRef]

11. Mikkola, M.S.; Rockward, T.; Uribe, F.A.; B. S. Pivovar, B. The effect of $\mathrm{NaCl}$ in the cathode air stream on PEMFC performance. Fuel Cells 2007, 7, 153-158. [CrossRef] 
12. Rotureau, D.; Viricelle, J.P.; Pijolat, C.; Caillol, N.; Pijolat, M. Development of a planar SOFC device using screen-printing technology. J. Eur. Ceram. Soc. 2005, 25, 2633-2636. [CrossRef]

13. Hildenbrand, N.; Boukamp, B.A.; Nammensma, P.; Blank, D.H. Improved cathode/electrolyte interface of SOFC. Solid State Ion. 2011, 192, 12-15. [CrossRef]

14. Goodhew, P.J.; Humphreys, J.; Beanland, R. Electron Microscopy and Analysis; CRC Press: Boca Raton, FL, USA, 2000.

15. Thambiraj, N.; Suciu, C.; Waernhus, I.; Vik, A.; Hoffmann, A.C. SOFC cathode degradation due to salt contamination. ECS Transactions 2017, 78, 915-925. [CrossRef]

16. Suciu, C.; Hoffmann, A.C.; Dorolti, E.; Tetean, R. NiO/YSZ nanoparticles obtained by new sol-gel route. Chem. Eng. J. 2008, 140, 586-592. [CrossRef]

17. Waldbillig, D.; Wood, A.; Ivey, D.G. Electrochemical and microstructural characterization of the redox tolerance of solid oxide fuel cell anodes. J. Power Sources 2005, 145, 206-215. [CrossRef]

18. Yonekura, T.; Tachikawa, Y.; Yoshizumi, T.; Shiratori, Y.; Ito, K.; Sasaki, K. Exchange Current Density of Solid Oxide Fuel Cell Electrodes. ECS Transactions 2011, 35, 1007-1014.

19. Bevc, F. Advances in solid oxide fuel cells and integrated power plants. Proc. Inst. Mech. Eng. Part A: J. Power Energy 1997, 211, 359-366. [CrossRef]

20. Shekhawat II, D.; Spivey, J.J.; Berry, D.A. Fuel Cells: Technologies for Fuel Processing: Technologies for Fuel Processing; Elsevier: Amsterdam, The Netherlands, 2011.

21. Sasaki, K.; Tamura, J.; Hosoda, H.; Lan, T.N.; Yasumoto, K.; Dokiya, M. Pt-perovskite cermet cathode for reduced-temperature SOFCs. Solid State Ion. 2002, 148, 259-271. [CrossRef]

22. Tietz, F. Peculiarities in the thermal expansion behavior of ceramic fuel cell materials. Adv. Sci. Technol. 1999, $61-70$. 